\title{
39. DATA REPORT: MAJOR-ELEMENT CHEMISTRY OF HOLE 896A GLASS ${ }^{1}$
}

\author{
Martin R. Fisk, ${ }^{2}$ Andrew W. McNeill,${ }^{3}$ Damon A.H. Teagle,${ }^{4}$ Harald Furnes,${ }^{5}$ and Wolfgang Bach ${ }^{6}$
}

\section{INTRODUCTION}

Ocean Drilling Program Hole $896 \mathrm{~A}\left(1^{\circ} 13.01^{\prime} \mathrm{N}, 83^{\circ} 43.39^{\prime} \mathrm{W}\right)$ is in $3440 \mathrm{~m}$ of water east of the Galapagos Platform in the equatorial eastern Pacific Ocean. At this site in 5.9 Ma crust, basement rocks were recovered over the depth range of 195.1 meters below seafloor (mbsf) to 469 mbsf. These rocks are mostly pillow lavas, but massive flows, breccias and dikes are also present. Many of the lavas and flows have quenched glass on their exteriors, and breccias commonly contain glass. Glass was analyzed by electron microprobe in six laboratories as part of shore-based studies of the rocks. These analyses are collected here so that all the chemical analyses are available in one publication. The analyses are interpreted in individual publications elsewhere in this volume.

\section{METHODS}

Analyses by Fisk were done on a 4-spectrometer CAMECA SX50 at Oregon State University (except for Sample 148-896A-12R-1, $52-55 \mathrm{~cm}$, which was analyzed with the nine-spectrometer ARL microprobe at the Smithsonian Institution). The CAMECA SX-50 analyses were conducted with an accelerating voltage of $15 \mathrm{kV}$, a beam current of $30 \mathrm{nA}$, and a beam diameter of $10 \mu \mathrm{m}$. The standards were basalt glass A-99 (Jarosewich et al., 1980) for $\mathrm{Si}, \mathrm{Ti}, \mathrm{Al}, \mathrm{Fe}$, and Ca. Mineral standards for the elements $\mathrm{Mg}, \mathrm{Na}, \mathrm{K}, \mathrm{Mn}, \mathrm{P}$, and $\mathrm{Cr}$ were Kakanui augite, Kakanui anorthoclase, Hohenfels sanidine, pyroxmangite, Durango fluorapatite, and Tiabaghi chromite, respectively. Counting times for all elements were $10 \mathrm{~s}$, except for aluminum and titanium, which were counted for $20 \mathrm{~s}$. Backgrounds were counted above and below the peaks for half of the peak counting time and background offsets were \pm 500 to \pm 700 units except for $\mathrm{Mg}$, which was \pm 1300 units to avoid interference from a higher order Ca peak. $\mathrm{Na}$ was always analyzed first. The PAP correction procedure supplied by Cameca was used to calculate the weight percentage of oxides from X-ray counts. Analyses of Sample 148-896A-12R-1, 52$55 \mathrm{~cm}$, with the ARL microprobe used a beam current of $150 \mathrm{nA}$ and an accelerating voltage of $15 \mathrm{kV}$. Standard glass A-99 was used to monitor the standardization during the analysis of Site 896 glass, and the averages and standard deviations of these analyses are given in Table 1.

'Alt, J.C., Kinoshita, H., Stokking, L.B., and Michael, P.J. (Eds.), 1996. Proc. ODP, Sci. Results, 148: College Station, TX (Ocean Drilling Program).

${ }^{2}$ College of Oceanic and Atmospheric Sciences, Oregon State University, Corvallis, OR 97331,U.S.A.mfisk@oce.orst.edu

${ }^{3}$ Geology Department, University of Tasmania, Hobart, Tasmania, 7001, Australia. andrew.mcneill@geol.utas.edu.au

${ }^{4}$ Department of Geological Sciences, The University of Michigan, 1006 C.C. Little Building. Ann Arbor, MI 48109-1063, U.S.A. teagle@umich.edu

${ }^{5}$ Geological Institute, University of Bergen, Allegaten 41, N-5007 Bergen, Norway. Harald.Furnes@geol.uib.no

${ }^{6}$ GeoForschungsZentrum Potsdam, Projektbereich 4.2, Telegrafenberg A50, D-14473 Potsdam, Federal Republic of Germany (present address: Universität Potsdam, Institut für Geowissenschaften, Postfach 601553, D-14415 Potsdam, Federal Republic of Germany). wbach@gfz-potsdam.de
Analyses by Teagle were made with a 4 -spectrometer CAMECA Camebax microprobe at the University of Michigan. The accelerating voltage was $15 \mathrm{kV}$ and the beam current was $10 \mathrm{nA}$. The beam was rastered over a $3 \times 3 \mu \mathrm{m}$ area, and the counting time for all elements was $30 \mathrm{~s}$. Background offsets were \pm 600 units, except for magnesium, which was \pm 750 units. Smithsonian glass standard VG-2 (Jarosewich et al., 1980) was used to calibrate silicon and aluminum. The other elements were standardized on minerals as follows: $\mathrm{K}$ and $\mathrm{Na}$ on feldspars, $\mathrm{Ca}$ on wollastonite, $\mathrm{Mg}$ on a magnesium-rich garnet, $\mathrm{Fe}$ on synthetic ferrosilicate, Ti on geikilite, Mn on a manganese oxide, $\mathrm{Cr}$ on a chrome-rich garnet, and $\mathrm{P}$ on a phosphate. The PAP correction procedure supplied by Cameca was used to calculate oxide weight percentages from X-ray intensities. Average analyses and standard deviations of standard glasses VG-2 and VGBS are given in Table 1.

Analyses by McNeill were done on a CAMECA SX-50 microprobe at the University of Tasmania. The accelerating voltage was 15 $\mathrm{kV}$ and the beam current was $20 \mathrm{nA}$. For analysis the beam was scanned over a $6 \times 4 \mu \mathrm{m}$ area. Counting times on peaks were $20 \mathrm{~s}$ for $\mathrm{Fe}$ and $\mathrm{K}$, and $10 \mathrm{~s}$ for the other elements. Backgrounds were counted for half of the peak-count time. Standards were: VG-2 for $\mathrm{Si}, \mathrm{Al}, \mathrm{Mg}$, and $\mathrm{Ca}$; Kakanui anorthoclase for $\mathrm{Na}$; Durango apatite for P; microcline (USNM 143966) for K; Ilmen Mt. ilmenite for Ti; and Tiebaghi chromite (USNM 117075) for chrome. The PAP correction procedure supplied by Cameca was used to convert intensities into oxide weight percent. Analyses of the standard VG-2 are given in Table 1.

Analyses by Furnes were done on a CAMECA Camebax microprobe using a $15 \mathrm{kV}$ accelerating voltage, a $5 \mathrm{nA}$ beam current, and a $1 \mu \mathrm{m}$ beam diameter. Peaks were counted for $10 \mathrm{~s}$ and the backgrounds for $5 \mathrm{~s}$. The standards used were wollastonite for $\mathrm{Si}$ and $\mathrm{Ca}$, $\mathrm{MnTi}$ alloy for $\mathrm{Mn}$ and $\mathrm{Ti}, \mathrm{Al}_{2} \mathrm{O}_{3}$ for $\mathrm{Al}, \mathrm{FeO}$ for $\mathrm{Fe}, \mathrm{MgO}$ for $\mathrm{Mg}$, omphacite for $\mathrm{Na}$, and orthoclase for $\mathrm{K}$. The correction procedure was MAGIC IV (Colby, 1968).

Analyses by Bach were done on a CAMECA SX-50 microprobe using $15 \mathrm{kV}$ accelerating voltage, a $20 \mathrm{nA}$ beam current, and a beam diameter of $20 \mu \mathrm{m}$. Peak intensities were counted for $20 \mathrm{~s}$, except for $\mathrm{K}$ and $\mathrm{P}$, for which $40 \mathrm{~s}$ count-times were used. Backgrounds were counted for half of the peak count-times and the correction procedure was the PAP program supplied by CAMECA. The pure mineral standards were used as, follows: wollastonite for $\mathrm{Si}$ and $\mathrm{Ca}, \mathrm{MnTiO}_{3}$ for $\mathrm{Ti}$ and $\mathrm{Mn}, \mathrm{Al}_{2} \mathrm{O}_{3}$ for $\mathrm{Al}, \mathrm{Fe}_{2} \mathrm{O}_{3}$ for $\mathrm{Fe}, \mathrm{MgO}$ for $\mathrm{Mg}$, albite for $\mathrm{Na}$, orthoclase for $\mathrm{K}, \mathrm{CePO}_{4}$ for $\mathrm{P}$, and $\mathrm{ZnS}$ for $\mathrm{S}$.

\section{RESULTS}

Average oxide abundances for glass from basalts from the five laboratories are presented in Figure 1 and Table 2. The data are arranged in order of increasing depth and " $\mathrm{N}$ " indicates the number of analyses in each average. Absence of $\mathrm{P}_{2} \mathrm{O}_{5}$ and $\mathrm{Cr}_{2} \mathrm{O}_{3}$ for some analyses indicates that these elements were not analyzed.

Interlaboratory comparisons of identical samples indicate that there are consistent differences for some of the elements (Fig. 2). For example, $\mathrm{SiO}_{2}$ values are consistently higher in the University of 
Table 1. Analysis of standards.

\begin{tabular}{|c|c|c|c|c|c|c|c|c|c|c|c|c|c|}
\hline Standard (analyst) & $N$ & $\mathrm{SiO}_{2}$ & $\mathrm{TiO}_{2}$ & $\mathrm{Al}_{2} \mathrm{O}_{3}$ & $\mathrm{FeO}^{*}$ & $\mathrm{MgO}$ & $\mathrm{CaO}$ & $\mathrm{Na}_{2} \mathrm{O}$ & $\mathrm{K}_{2} \mathrm{O}$ & $\mathrm{MnO}$ & $\mathrm{P}_{2} \mathrm{O}_{5}$ & $\mathrm{Cr}_{2} \mathrm{O}_{3}$ & Total \\
\hline VG-2 published (Jarosewich et al., 1980) & & 50.81 & 1.85 & 14.06 & 11.84 & 6.71 & 11.12 & 2.62 & 0.19 & 0.22 & 0.20 & & 99.62 \\
\hline \multirow[t]{2}{*}{ VG-2 average (Teagle) } & 25 & 51.18 & 1.83 & 14.02 & 11.66 & 6.67 & 10.83 & 2.62 & 0.20 & 0.22 & 0.18 & 0.02 & 99.42 \\
\hline & Is & 0.59 & 0.04 & 0.08 & 0.17 & 0.08 & 0.08 & 0.06 & 0.01 & 0.03 & 0.02 & 0.02 & \\
\hline \multirow[t]{2}{*}{ VG-2 average (McNeill) } & 9 & 50.36 & 1.85 & 14.23 & 11.98 & 6.78 & 10.89 & 2.50 & 0.20 & 0.18 & 0.22 & & 99.19 \\
\hline & Is & 0.18 & 0.01 & 0.08 & 0.30 & 0.07 & 0.06 & 0.01 & .001 & 0.01 & 0.06 & & \\
\hline VGBS published (Jarosewich et al., 1980) & & 51.52 & 1.30 & 15.39 & 9.13 & 8.21 & 11.31 & 2.48 & 0.09 & 0.17 & 0.12 & & 99.72 \\
\hline \multirow[t]{2}{*}{ VGBS average (Teagle) } & 19 & 52.14 & 1.30 & 15.37 & 9.20 & 7.86 & 11.10 & 2.65 & 0.08 & 0.16 & 0.10 & 0.03 & 99.99 \\
\hline & Is & 0.41 & 0.04 & 0.11 & 0.15 & 0.07 & 0.10 & 0.05 & 0.01 & 0.03 & 0.02 & 0.02 & \\
\hline A-99 published (Jarosewich et al., 1980) & & 50.94 & 4.06 & 12.49 & 13.30 & 5.08 & 9.30 & 2.66 & 0.82 & 0.15 & 0.38 & & 99.19 \\
\hline \multirow[t]{2}{*}{ A-99 average (Fisk session 1) } & 14 & 50.70 & 4.05 & 12.58 & 13.32 & 5.02 & 9.30 & 2.63 & 0.84 & 0.19 & 0.45 & 0.01 & 99.09 \\
\hline & Is & 0.16 & 0.05 & 0.06 & 0.15 & 0.08 & 0.13 & 0.08 & 0.02 & 0.03 & 0.05 & 0.01 & \\
\hline \multirow[t]{2}{*}{ A-99 average (Fisk session 2) } & 15 & 50.98 & 4.04 & 12.39 & 13.15 & 5.06 & 9.12 & 2.65 & 0.84 & 0.18 & 0.45 & 0.02 & 98.90 \\
\hline & Is & 0.17 & 0.08 & 0.08 & 0.14 & 0.05 & 0.31 & 0.06 & 0.02 & 0.04 & 0.04 & 0.02 & \\
\hline \multirow[t]{2}{*}{ A-99 average (Fisk session 3 ) } & 16 & 50.83 & 4.01 & 12.43 & $\begin{array}{r}13.28 \\
0.10\end{array}$ & 5.11 & 9.27 & 2.66 & 0.84 & 0.19 & 0.45 & 0.02 & 99.10 \\
\hline & Is & 0.26 & 0.11 & 0.09 & 0.19 & 0.06 & 0.13 & 0.06 & 0.02 & 0.03 & 0.04 & 0.02 & \\
\hline
\end{tabular}

Notes: $N=$ number of analyses in average. $\mathrm{FeO}^{*}=$ all iron as $\mathrm{FeO}$.
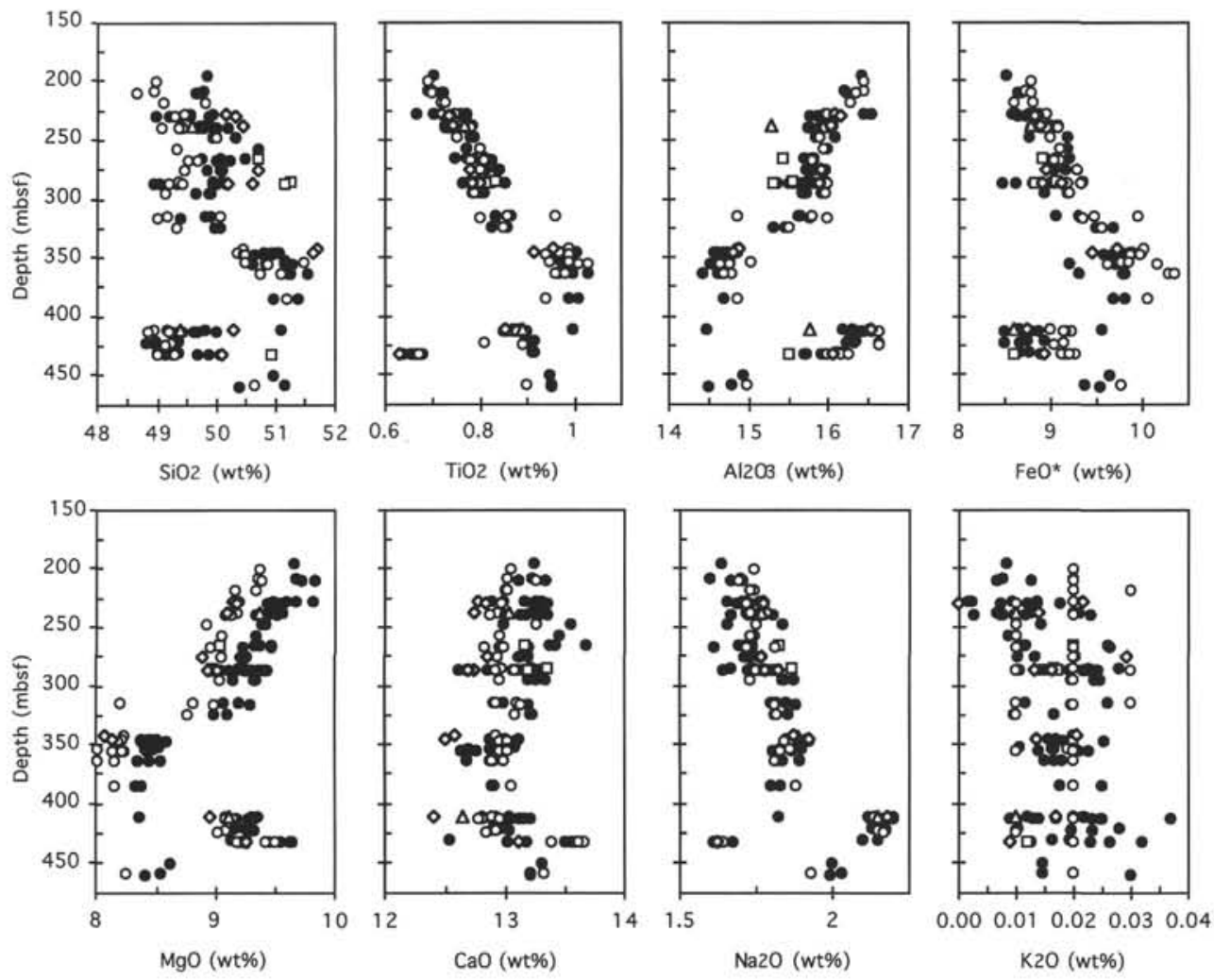

Figure 1. Glass chemistry analyses from Hole $896 \mathrm{~A}$ by five laboratories plotted vs. depth. Solid circles $=$ Fisk, open circles $=$ McNeill, diamonds $=$ Teagle, squares $=$ Furnes, and triangles $=$ Bach.

Michigan analyses (Teagle) than in those of Oregon State University (Fisk), and $\mathrm{MgO}$ and $\mathrm{CaO}$ values of Teagle are consistently lower than those of Fisk. The MgO measured using the microprobe at Oregon State University is consistently $0.25 \mathrm{wt} \%$ higher than the $\mathrm{MgO}$ from the other laboratories.

This difference is not related to differences in instruments, to correction procedure, or to accelerating voltage because all laboratories used Cameca instruments, $15 \mathrm{kV}$ accelerating voltages, and PAP correction procedures. Differences between laboratories, however, may be related to the standards used, the beam conditions (beam current, and beam diameter), and counting strategies (background offsets, counting times, and rastered vs. stationary beam). Because of the number of variables, it is not possible to determine which of these resulted in the differences in $\mathrm{Si}, \mathrm{Mg}$, and $\mathrm{Ca}$ in the three laboratories with the most data. One factor that may contribute to the differences of $\mathrm{MgO}$ by the different laboratories is the position of the background offset for $\mathrm{Mg}$. Oregon State University analyses used a larger background offset for $\mathrm{Mg}$ than the other laboratories which may have resulted in lower $\mathrm{Mg}$ background intensities, and thus larger peakminus-background values.

The average of $25 \mathrm{MgO}$ analyses of VG-2 by Teagle (Table 1) is within $1 \sigma$ of the reported value (Jarosewich et al., 1980), but the 19 analyses for VGBS by Teagle have an average $\mathrm{MgO}$ that is $0.35 \mathrm{wt} \%$ (this is $5 \sigma$ ) below the reported value (Jarosewich et al., 1980). It is 
Table 2. Microprobe analyses of Hole 896A glass.

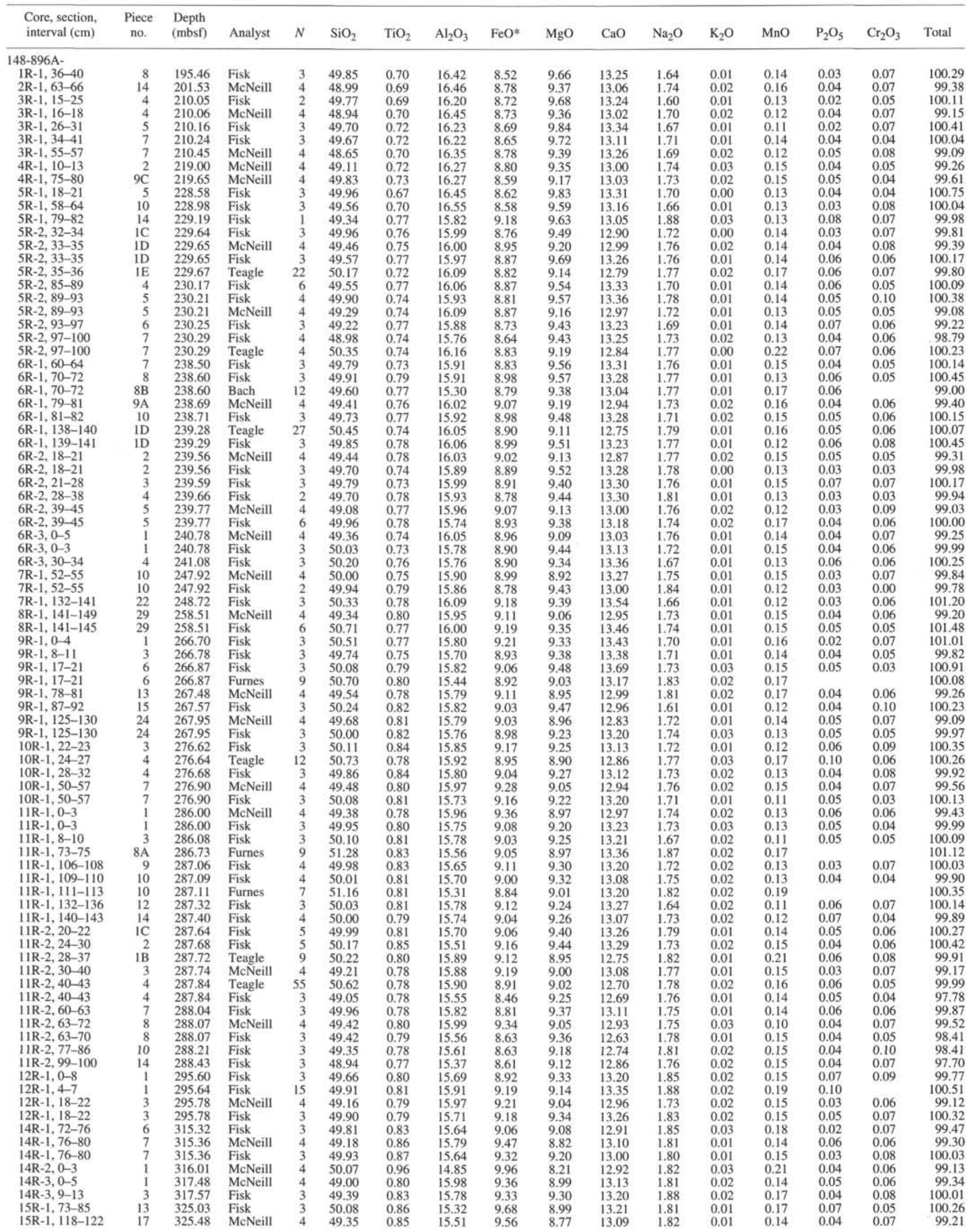


Table 2 (continued).



Note: $N=$ number of analyses.

possible that this results from inhomogeneity of the glass standard VGBS.

The complete data set, except for $\mathrm{P}$ and $\mathrm{Mn}$, is presented as a function of depth (Fig. 1). This figure shows the similarities and differences of analyses from the same samples analyzed by different microprobes. All laboratories show a consistent increase in $\mathrm{TiO}_{2}$, $\mathrm{FeO}^{*}$, and $\mathrm{Na}_{2} \mathrm{O}$, and a decrease in $\mathrm{Al}_{2} \mathrm{O}_{3}$ and $\mathrm{MgO}$ with depth. Interpretation of the glass chemistry is presented in other publications in this volume.

\section{CONCLUSIONS}

Glasses from Hole 896A were analyzed for major elements by electron microprobes in six different laboratories. Analyses of identical samples by different laboratories show that there are interlaboratory differences for some elements, notably $\mathrm{MgO}$. Other elements $\left(\mathrm{TiO}_{2}\right.$, for example) are remarkably similar. The complete data set can be obtained from the authors over Internet. 

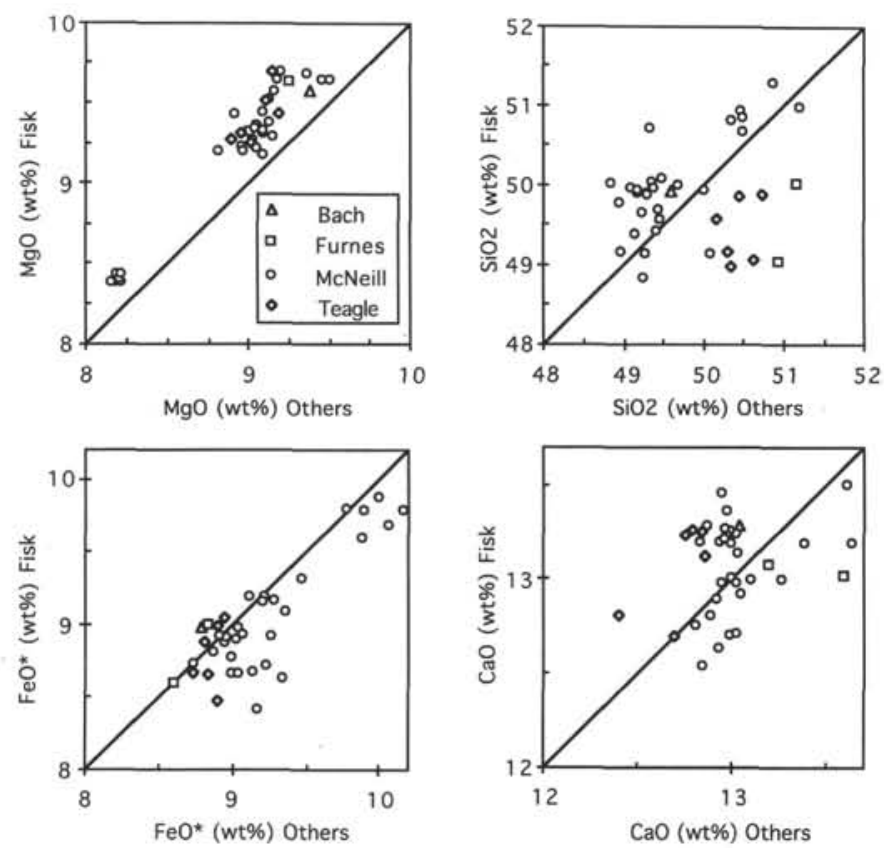

Figure 2. Comparison of microprobe analyses of $\mathrm{MgO}, \mathrm{SiO}_{2}, \mathrm{FeO}^{*}$, and $\mathrm{CaO}$ from the five laboratories. Analyses from the Oregon State University microprobe are plotted vs. analyses of glass from the same piece by other laboratories.

\section{ACKNOWLEDGMENTS}

We wish to thank Gene Jarosewich and Joe Nelen of the Smithsonian, and Roger Nielsen of Oregon State University for help with microprobe analyses. Thanks to John Bender and Michael Perfit for helpful reviews.

\section{REFERENCES}

Colby, J.B., 1968. MAGIC IV - computer program for quantitative electron microprobe analysis. Adv. X-Ray Anal., 11:287-306.

Jarosewich, E., Nelen, J.A., and Norberg, J.A., 1980. Reference samples for electron microprobe analysis. Geostand. Newsl., 4:43-47.

Date of initial receipt: 19 August 1994

Date of acceptance: 2 January 1995

Ms 148SR-105 